\title{
A Correlational Study Between Some Motivational Constructs and EFL Writing Performance in a Blended Learning Environment
}

\author{
Eman Abdel-Reheem Amin ${ }^{1}$ \\ ${ }^{1}$ Assistant professor, English Language Department, Zulfi College of Education, Majmaah University, Saudi \\ Arabia \\ Correspondence: Eman Abdel-Reheem Amin. Department of English Language, Zulfi College of Education, \\ Majmmah University, Majmaah 11952, Saudi Arabia. E-mail: e.abdelrahim@mu.edu.sa
}

Received: March 12, 2019 Accepted: April 18, 2019 Online Published: May 8, 2019

doi:10.5539/ijel.v9n3p238 URL: https://doi.org/10.5539/ijel.v9n3p238

\begin{abstract}
The present study examined the correlation between some motivational constructs and writing performance of EFL university students. Participants were female students enrolled in an English language writing course at Zulfi College of Education. Participants studied writing essays in a blended learning environment i.e., in regular classroom lectures and online via Desire2Learn (D2L) learning tools. Participants' writing motivation was measured by a Motivational Writing Questionnaire (MWQ). Their writing performance was assessed by an EFL Writing Performance Test (WPT). For analyzing data, SPSS was used. A Pearson correlation analysis was calculated to explore the correlation between four writing motivational constructs: intrinsic motivation, extrinsic motivation, self-efficacy, and effort, and writing performance. Findings indicated a significant and positive correlation between writing motivational constructs and writing performance in a blended learning environment.
\end{abstract}

Keywords: blended-learning, D2L, EFL, writing motivation, writing performance

\section{Introduction}

Writing skill encourages thinking, communication and reflection of thoughts (Scott, 2008; Seliem \& Ahmed, 2009). In spite of its importance, writing skill is complicated, because it is affected by some aspects. It is influenced by students' syntactical and lexical knowledge as well as metacognitive skills to organize and develop ideas to write essays (Graham, 2008; Aydin \& Yildiz, 2014). Besides, motivation affects students' writing performance. Highly motivated students are willing to perform better in writing tasks. On the contrary, demotivated students give up easily in the face of difficulties within writing tasks (Amin, 2016). In the meanwhile, some factors may affect students' motivation towards writing such as the complexity of topics, specifying certain essay topics, emphasize on grades, focus on the form only, following the product approach, and little feedback from teachers and peers (Oldfather \& Shanahan, 2007). Furthermore, attitudes, anxiety, self-efficacy beliefs, self-regulation, and motivation are motivational factors that could lead to difficulties in writing performance (El-Sayed, 2012; Fathi, 2013; Hidi \& Boscolo, 2006; Mohammed, 2010). Accordingly, the relationship among writing performance and constructs of motivation has been the subject of some previous writing researches (e.g., Abu Kassim, Daud, \& Daud, 2013; Lam \& Law, 2010; Prat-Sala \& Redford, 2010; Soureshjani, 2013; Troia, Shankland, Wolbers, \& Lawrence, 2013). They proved a positive correlation between writing motivation and performance.

\subsection{Statement of the Problem}

It is supposed by some researches that students' poor EFL writing performance may be related to their low level of writing motivation. Previous researchers have thoroughly investigated the relationship between motivational constructs and writing performance in traditional face-to-face classes. Few studies have investigated this relationship in a blended learning environment (Miltiadou \& Savenye, 2003). Therefore, the present study was conducted to investigate the correlation between four motivational constructs and EFL writing performance in a blended learning environment. Hence, the following main question was attempted: does a relationship exist between some motivational constructs (i.e., intrinsic-, extrinsic motivation, self-efficacy, and effort) and EFL writing performance in a blended learning environment? 


\subsection{Research Hypotheses}

The study hypothesized that:

1) Students' writing motivation is positively correlated to their EFL writing performance.

2) Students' intrinsic motivation towards writing is positively correlated to their EFL writing performance.

3) Students' extrinsic motivation towards writing is positively correlated to their EFL writing performance.

4) Students' self-efficacy in writing is positively correlated to their EFL writing performance.

5) Students' effort in writing is positively correlated to their EFL writing performance.

6) Students' writing motivation is inversely correlated to their EFL writing performance.

\section{Review of Literature}

\subsection{Writing Motivation}

Motivation means exerting more efforts to accomplish certain tasks. It may be intrinsic or extrinsic. Indeed, motivation has some constructs which affect students' process of learning and achievement. Examples of these constructs are self-efficacy, self-regulation, goal orientation, the locus of control, attribution, and efforts (Miltiadou \& Savenye, 2003). If learners are highly motivated, they exert more efforts during their learning (Gholami, Allahyar, \& Rafik-Galea, 2012)

Intrinsic motivation towards writing is related to students' engagement in writing tasks for inherent satisfaction. One method for fostering students' intrinsic motivation is to provide them with a list of topics to choose from. The reason behind this is that intrinsic motivation occurs for the activities that learners like (Rayn \& Deci, 2000). On the other hand, positive comments and corrective feedback are sources of external satisfaction that enhance students' extrinsic motivation. Developing students' extrinsic motivation results in better writing performance (Abu Kassim, Daud, \& Daud, 2013; Amin, 2016).

Writing motivation constructs also incorporate writing self-efficacy. Having high self-efficacy enables students to consider writing tasks as challenges rather than as threats (Pajares, 2003). Prat-Sala and Redford (2010) explored and affirmed the interrelationships among intrinsic and extrinsic motivation, writing self-efficacy, and studying approaches. The results of correlation analyses conducted by Zhang and Guo (2013) concluded that a positive correlation exists among self-efficacy and English writing proficiency and writing motivation. Other studies pinpointed the importance of self-efficacy as one component of motivation in developing students' writing performance (Garcia \& de Caso, 2004).

Effort is a further construct of motivation. It implies a tendency and willingness to expand efforts to pursue goals. It is affirmed that students' writing performance is influenced by sustained efforts on writing (Hidi \& Boscolo, 2006). In other words, if they are motivated enough, they will exert much effort in their writings. Moreover, writing performance involves organizational planning, so it needs a great effort (Longknife \& Sullivan, 2012).

Previous studies investigated the correlation between writing motivational constructs and writing performance. For example, Lam and Law (2010) and Abu Kassim, Daud and Daud (2013) concluded that motivation affects students' writing performance. Soureshjani (2013) indicated that motivation, self-regulation, and writing performance are positively correlated. A similar conclusion was drawn by Troia, Shankland, Wolbers, and Lawrence (2013). Moreover, academic motivation and learning approaches may explain academic performance. For instance, Çetin (2015) found out that academic learning approaches and motivation are correlated. Besides, motivational orientations affect students' engagement and performance in online writing classes (Hobson \& Puruhito, 2018).

\subsection{Writing Performance}

Writing performance implies writing with a perfect organization of ideas and paragraphs, relevant and adequate content, accurate sentence structure, and appropriate conventions and mechanics. Therefore, writing is a skill that can be mastered through following certain stages, for instance, outlining, and drafting, proofreading, and editing (Tompkins, 2010). Thus, writing performance goes through certain successive stages. At first, the prewriting stage involves brainstorming of ideas. Then students outline their ideas and paragraphs. Next, they start writing their drafts and editing them. Finally, they edit and proofreading their writings (Oshima \& Hogue, 2007).

The significance of training the students through the process of writing was emphasized in studies of $\mathrm{He}$ and Shum (2005); Tobin, (2001); Mostafa (2002); Lam (2007); Longknife and Sullivan (2012). Teaching students 
the stages of writing needs time; furthermore, students require opportunities to practice it. Therefore, blended learning is encouraged for teaching writing.

\subsection{Blended Learning and Writing Performance}

Blended learning is a learning approach in which a significant amount of classroom time is replaced with online activities to meet course objectives (Blin \& Jalkanen, 2014; Glazer, 2012). It integrates the features of online and traditional face-to-face learning. In other words, blended learning has the merits of these two methods of learning. Recent surveys in higher education showed that a high percentage of institutions and colleges offer blended learning courses. This tendency implies its effectiveness in the learning and teaching process (Garrison \& Vaughan, 2008). Researchers pinpointed that a relationship exists between students' experiences and their academic performance in blended or online courses (Kumi Yeboah \& Smith, 2016).

Blended learning within writing courses has not only facilitated the process of teaching but also has improved students' writing performance as well. Fahim (2011) pinpointed that implementing the process writing approach through weblogs enhanced students' writing performance. So and Lee (2013) concluded that using an instructional model in writing in blended learning developed L2 writing skills in higher education. Camahalan and Ruley (2014) proved the effectiveness of using a blended learning process in the classroom in improving students writing. Due to the importance of blended learning and integration of technology in teaching writing, Yang (2014) examined teachers' problems in using blended learning in writing courses and then presented related solutions.

Blended learning is encouraged in Arab countries such as KSA, as its universities try to deliver quality education. One criterion for achieving this objective is combining online learning within regular classes (Aljahni, Al-Begain, \& Skinner, 2014). Accordingly, due to the significance of blended learning in enhancing learners' writing performance, the present study participants studied writing in that environment, where they attended face-to-face classes and also completed their learning and practice online through D2L system. It offers a variety of online learning tools and includes user account for both the class instructor and the students. Besides, it offers tools to include discussion forums, modules, news tools, online quizzes, Gradebooks, and Dropbox. Therefore, D2L is an online learning management system (LMS), that enables the interaction between learners, instructors, and course content (Fahrni, Rudolph, \& De Schutter, 2004). It is assumed that teaching writing is facilitated through these features (Amin, 2016; So \& Lee, 2013).

\section{Method}

\subsection{Participants}

Sixty female students, aged 18-23, at the English Language Department in Zulfi College of Education, Majmaah University, Saudi Arabia, participated in the study. They were enrolled at the 6th level Advanced Writing classes. Neither age nor gender was considered as variables in this study. Participants studied in a blended-learning environment where they studied writing essays in-and-out the classroom.

\subsection{Materials}

\subsubsection{A Motivational Writing Questionnaire (MWQ)}

The WMQ aims at measuring students' writing motivation level. It was adapted from Amin (2016). The questionnaire consisted of 36 items to investigate four aspects of motivation: students' intrinsic and extrinsic motivation, self-efficacy and effort. Responses were measured on a Likert five-rating scale (see Appendix A). The WMQ was designed using D2L Survey Tools.

\subsubsection{A Writing Performance Test (WPT)}

The WPT measures three aspects of writing performance: development, organization, and conventions. Students were given prompts to write an essay on one of three topics (see Appendix B). The test is scored on the criteria of the writing performance rubric.

\subsubsection{A Writing Performance Rubric (WPR)}

The WPR was used to score students' writing performance. It was adapted from Rich, Schneider, D' Brot (2013, pp. 108-109) and Amin (2016) (See Appendix C).

\subsection{Procedures and Data Collection}

The correlation between motivational constructs and EFL writing performance was measured for 60 participants from the English language department. Students' motivation towards writing was examined via MWQ. The 
questionnaire was distributed electronically among the participants via its URL link. Instructions of the questionnaire were illustrated to them before starting submitting their responses.

The WPT was used to measure students' writing performance, and it was administered during their lecture. Data obtained through the WMQ and the WPT was used to investigate the relationship between four motivational constructs: intrinsic motivation, extrinsic motivation, self-efficacy and effort, and students' writing performance. Statistical data were analyzed using SPSS. Results are presented below.

\section{Results}

In analyzing the data, descriptive statistics and Pearson correlation were conducted as shown in the following tables.

\subsection{Descriptive Statistics}

Table 1 gives information about the results of the descriptive statistics of the EFL Writing Performance Test.

Table 1. Descriptive statistics of the WPT

\begin{tabular}{llllll}
\hline No. of participants & No. of items & Min. & Max. & Mean & SD \\
\hline 60 & 1 & 15 & 23 & 19.50 & 1.68 \\
\hline
\end{tabular}

In Table 1, the participants' number is 60 , and their scores on the test ranged from a minimum of 15 to a maximum of 23, with a mean of 19.50 and a standard deviation of 1.68 . This result means that the sample size was adequate to analyze hypotheses for this study. The mean scores indicate that their writing performance was relatively good.

Table 2 provides results of the descriptive statistics of the Writing Motivation Questionnaire (WMQ)

Table 2. Descriptive statistics of the WMQ

\begin{tabular}{lllllll}
\hline WMQ/Constructs & No. of participants & No. of items & Min. & Max. & Mean & SD \\
\hline Total & 60 & 36 & 55 & 142 & 103.95 & 22.81 \\
Intrinsic & 60 & 12 & 15 & 50 & 31.31 & 7.41 \\
Extrinsic & 60 & 8 & 12 & 38 & 23.68 & 7.43 \\
Self-efficacy & 60 & 8 & 12 & 40 & 26.50 & 6.98 \\
Effort & 60 & 5 & 10 & 30 & 22.45 & 7.16 \\
\hline
\end{tabular}

As shown in Table 2, the participants' minimum score on the WMQ was 55, whereas the maximum score was 142 with a mean of 103.95 and a standard deviation of 22.81. The table also shows the minimum and maximum scores, means, and the standard deviation of each motivation construct. In Table 2, participants showed a high motivation towards writing (103.9); their intrinsic motivation is the highest motivational construct (31.3); their extrinsic motivation is the least effective variable for students' motivation towards writing; they had high levels of self-efficacy in writing (26.5), and they exerted relatively great efforts in writing (22.4).

\subsection{Pearson Correlations}

Table 3 shows the findings of Pearson correlations between the total scores of the Writing Motivation Questionnaire (WMQ) and Writing Performance Test (WPT)

Table 3. The correlation between WMQ and WPT

\begin{tabular}{llll} 
& & WPT & WMQ \\
\hline WPT & Pearson Correlation & 1 & $.750\left(^{* *}\right)$ \\
& Sig. (2-tailed) &. & .000 \\
& $\mathrm{~N}$ & 60 & 60 \\
WMQ & Pearson Correlation & $.750\left(^{* *}\right)$ & 1 \\
& Sig. (2-tailed) & .000 &. \\
& $\mathrm{~N}$ & 60 & 60 \\
\hline
\end{tabular}

Note. ${ }^{* *}$ Correlation is significant at the 0.01 level (2-tailed). 
Results of Table 3 revealed a significant positive correlation between the students' writing motivation and their EFL writing performance $(r=.773, p<.01)$. Accordingly, the first hypothesis is proven to be true.

Table 4 presents the results of Pearson correlations between each of the four motivation constructs scores on the Writing Motivation Questionnaire (WMQ) and EFL Writing Performance Test (WPT)

Table 4. The correlation between each of the four motivational constructs' scores on the WMQ and WPT.

\begin{tabular}{llllll}
\hline & & Intrinsic motivation & Extrinsic motivation & Self-efficacy & Effort \\
\hline \multirow{2}{*}{ WPT } & Pearson correlation & $.650^{* *}$ & $.476^{* *}$ & $.572^{* *}$ & $.665^{* *}$ \\
& Sig. (2-tailed) & .000 & .000 & .000 & .000 \\
& $\mathrm{~N}$ & 60 & 60 & 60 & 60 \\
\hline
\end{tabular}

Note. ${ }^{*}$ Correlation is significant at the 0.01 level (2-tailed).

Table 4 demonstrates that students' writing performance is positively and significantly correlated with all of the motivational constructs as follows: intrinsic motivation $(\mathrm{r}=.650, \mathrm{p}<.01)$, extrinsic motivation $(\mathrm{r}=.476, \mathrm{p}<.01)$, self-efficacy $(\mathrm{r}=.572, \mathrm{p}<.01)$ and effort $(\mathrm{r}=.665, \mathrm{p}<.01)$. Accordingly, the second, third, fourth and fifth hypotheses are proven to be true, but the sixth hypothesis is rejected.

\section{Discussion}

The results showed a statistically significant positive correlation between writing motivation and writing performance of the participants. This result, particularly, revealed a positive correlation between the four motivational constructs towards writing and students' EFL writing performance. These findings are consistent with those of Daly and Sharko (2010) and Abu Kassim, Daud and Daud (2013). Researchers such as Lam and Law (2010) concluded that motivating the students to write results in better performance in their writings. Other studies examined the strength of motivation and its relation to writing performance such as Soureshjani (2013) and Troia, Shankland, Wolbers, and Lawrence (2012). They agreed that there was a positive correlation between students' writing performance and their level of motivation.

The results of the study also indicated that the participants were motivated towards writing. They showed much interest in their performance than demotivated students. Highly motivated students tended to complete their writing tasks as soon as possible to get their writings published on D2L news and forum tools. Although some students tried to do their best in their writings, there were mistakes in sentence structures and grammar. This result may mean that highly motivated students are not necessarily highly qualified or competent in their writings. In other words, the correlation between motivation towards writing and writing performance exists regardless of students' level in writing skills. This finding is congruent with other writing and motivation researches such as Amin (2016) who concluded that students' writing performance, apart from their skills (e.g., sentence structure, mechanics and word choice), was affected by their motivation towards writing.

Participants' intrinsic motivation is positively correlated with their writing performance. One reason for stimulating the participants' creativity and motivation for writing may be integrating D2L tools in their writing class. In their study Fahrni, Rudolph and De Schutter (2004) concluded that D2L is easy to integrate with teaching classes and has a high degree of usability. Students at Zulfi College of Education were trained to use D2L. Therefore, the study participants easily used D2L options, especially collaboration and discussion tools. D2L tools helped them to have a significant role in their learning by regulating and controlling it, and consequently, it improved their intrinsic motivation.

Besides, students' extrinsic motivation was significantly correlated with their writing performance. External satisfaction and rewards are the best ways for attaining extrinsic motivation (Rayn \& Deci, 2000). Positive comments and corrective feedback that was given to the students via the D2L discussion tool boosted their extrinsic motivation. Moreover, students' discussions and comments on their essays and their assignments were graded via D2L. Hence, their extrinsic motivation affected their writing performance, for their motivation towards writing increased. In her study, Abu Kassim, Daud, and Daud (2013) indicated that combined psychological factors such as writing apprehension and extrinsic and intrinsic motivation had a substantial influence over learners' writing performance.

The present study demonstrated that the participants' self-efficacy towards writing was correlated with their writing performance. Writing self-efficacy is sometimes treated as a construct of motivation since it influences students' persistence and effort in conducting writing assignments. Students with a high level of self-efficacy in writing tended to be more motivated and have a positive attitude towards writing. This result is consistent with 
Zhang and Guo (2012) who indicated a significant correlation among writing motivation, self-efficacy and writing proficiency. Besides, publishing outstanding writing assignments of some students, in the class D2L forum page, is an example of vicarious experience which enhanced learners' writing self-efficacy.

Indeed, the findings of the study indicated a highly-positive correlation between students writing performance and effort. Students exerted efforts on each stage of writing. D2L facilitated writing as a process in which motivated students tended to exert great efforts in their writings. The Discussion Threads on D2L is one of the tools which motivated students to participate. Using this tool increased students' efforts and collaboration and facilitated their interaction. The same results were affirmed by Moallem (2003).

Generally, without sufficient motivation towards writing, learners were not willing to accomplish their writing tasks. On the contrary, motivated learners were eager to complete their writing assignments. Motivation towards writing promoted their persistence in writing activities. In other words, students' effort towards writing affected their motivation and consequently their performance in writing. The more they were motivated, the more efforts they exerted in their writings. The same conclusion was drawn by Hashemiana and Heidarib (2013).

\section{Conclusions and Recommendations}

To conclude, the present study investigated the correlation between four components of motivation towards writing and students' writing performance in a blended learning environment. The following are the major findings of the study:

1) The participants' motivation towards writing is significantly correlated with their writing performance.

2) Students' effort in writing is the highest motivational construct that positively correlated with their writing performance.

3) The least correlation scores go for students' extrinsic motivation.

4) Students' self-efficacy in writing is positively and significantly correlated with their writing performance.

Thus, the study participants had a relatively high overall motivation for writing. They studied writing in a blended-learning environment where they attended their regular writing lectures, and then they completed their writing practice online via D2L tools. Students' high motivation towards writing may be due to that method (i.e., learning in a blended-learning environment). Part of the class time was supplemented by online learning experiences, and so the students found more time to practice writing. Therefore, it is recommended to teach the writing process in a blended learning environment since writing as a skill needs more time and practice.

In such a blended learning environment, both online and in-class learning experiences would parallel and complement each other. In the present study, this variation of learning methods motivates students towards writing which might positively affect their writing performance. To sum up, employing a blended learning environment and having motivation towards writing might lead to effective writing performance. The positive correlation between writing performance and motivation is related to motivated learners' intrinsic motivation, extrinsic motivation, writing self-efficacy and efforts to develop accurate and well-organized essays.

The findings of the present study are limited since the participants were only female students. It is recommended to replicate the study to compare the findings with male students. The correlation among other motivational factors and writing performance, need to be investigated. A similar study could be conducted, in a traditional classroom setting, and then comparing the results with those of the present study to isolate the effect of blended learning. It is also recommended to carry out a more comprehensive study which examines the effect of more variables such as grade, gender, and ability in investigating the relationship between writing motivation and writing performance.

Based on the correlational nature of this research, some experimental studies can be developed to raise writing motivational level or writing performance. Learning and teaching activities or tasks may be designed or organized to boost levels of motivation and enhance writing performance in further studies.

\section{Acknowledgements}

The author would like to thank Deanship of Scientific Research at Majmaah University for supporting this work under project No. 1440-90.

\section{References}

Abu Kassim, N., Daud, N. M., \& Daud, N. S. (2013). Interaction between writing apprehension, motivation, attitude and writing performance: A structural equation modeling approach. World Applied Sciences Journal 21 (Special Issue of Studies in Language Teaching and Learning),102-108. 
Aljahni, A., Al-Begain, K., \& Skinner, H. (2014). Development and validation of the blended learning environment instrument (BLEI) in higher education. Journal of Interactive Learning Research, 25(4), 453465. https://doi.org/10.1037/t54766-000

Amin, E. (2016). Using "Wikis" in developing writing performance and motivation among EFL students at Majmaah University. Faculty of Education Journal (Benha University), 27(105), 1-29. https://doi.org/10.12816/0028199

Aydin, Z., \& Yildiz, S. (2014). Using wikis to promote collaborative EFL writing. Language Learning \& Technology, 18(1), 160-180. Retrieved from http://1t.msu.edu/issues/february2014/aydinyildiz.pdf

Blin, F., \& Jalkanen, J. (2014). Designing for Language Learning: Agency and language in hybrid environments. Apples. Journal of Applied Language Studies, 8(1), 147-170. Retrieved from http://apples.jyu.fi/ArticleFile/download/433

Camahalan, F. M. G., \& Ruley, A. G. (2014). Blended learning and teaching writing: A teacher action research project. Journal of Instructional Pedagogies, 15, 1-13. Retrieved from https://files.eric.ed.gov/fulltext/EJ1060103.pdf

Çetin, B. (2015). Predicting academic success from academic motivation and learning approaches in classroom teaching students. Contemporary Issues in Education Research - Third Quarter, 8(3), 1-10. https://doi.org/10.19030/cier.v8i3.9316

Daly, L., \& Sharko, S. (2010). Motivating students to write through the use of children's literature. Master of Arts Action Research Project, Saint Xavier University. Retrieved from https://files.eric.ed.gov/fulltext/ED509396.pdf

El-Sayed, A. (2012). Using different types of corrective feedback to develop first secondary school students' writing attitude and performance. Ph.D dissertation, Cairo University, Institute of Educational studies. Retrieved from http://erepository.cu.edu.eg/index.php/cutheses/article/view/2782

Fahim, S. M. (2011). A proposed program based on blending process writing approach with web logs to develop the writing performance and critical reading of EFL prospective teachers. Journal of the Faculty of Education Suez, 1(4), 1-44. Retrieved from https://platform.almanhal.com/Details/article/7031

Fahrni, P., Rudolph, J., \& De Schutter, A. (2004). Technical Evaluation Report 30. Vendor-Assisted Evaluation of a Learning Management System. International Review of Research in Open and Distance Learning, 5(1), 1-4. https://doi.org/10.19173/irrodl.v5il.162

Fathi, M. (2013). A suggested learning strategy based on self-assessment for developing some EFL writing skills and reducing writing anxiety level among first year secondary school students. MA Thesis, Cairo University, Institute of Educational Studies.

García, J.-N., \& de Caso, A. M. (2004). Effects of a Motivational Intervention for Improving the Writing of Children with Learning Disabilities. Learning Disability Quarterly, 27(3), 141-159. https://doi.org/10.2307/1593665

Garrison, D. R., \& Vaughan, N. D. (2008). Blended learning in higher education: Framework, principles, and guidelines. San Francisco: Jossey-Bass.

Gholami, R., Allahyar, N., \& Rafik-Galea, S. (2012). Integrative motivation as an essential determinant of achievement: A case of EFL high school students. World Applied Sciences Journal, 17(11), 1416-1424. Retrieved from https://pdfs.semanticscholar.org/1d3d/840b64e13a7a8950bef428b022efc58b5336.pdf

Glazer, F. S. (2012). Blended learning: Across the disciplines, across the academy. Sterling, Virginia: Stylus Publ.

Graham, S. (2008). Effective writing instruction for all students: Written for renaissance learning. USA: Renaissance Learning, Inc.

Hashemiana, M., \& Heidarib, A. (2013). The relationship between L2 learners' motivation/attitude and success in L2 writing. Procedia - Social and Behavioral Sciences, 70(5), 476-489. https://doi.org/10.1016/j.sbspro.2013.01.085

He, K., \& Shum, M. (2005). The study of psychological model and teaching approaches: Primary school composition. In D. Zhang \& M. Shum (Eds.), Teaching writing in Chinese speaking areas (pp. 109-130). NY: Springer Science Media, Inc. 
Hidi, S., \& Boscolo, P. (2006). Motivation and writing. In C. A. MacArthur, S. Graham \& J. Fitzgerald (Eds.), Handbook of Writing Research (pp. 144-157). N.Y: The Guilford Press.

Hobson, T., \& Puruhito, K. (2018). Going the Distance - Online Course Performance and Motivation of Distance-Learning Students. Online Learning, 22(4), 129-140. https://doi.org/10.24059/olj.v22i4.1516

Kumi, Y. A., \& Smith, P. (2016). Relationships Between Minority Students Online Learning Experiences and Academic Performance. Online Learning, 20(4). https://doi.org/10.24059/olj.v20i4.577

Lam, S. (2007). An action research project to explore the effects of collaborative learning on students' writing quality and their conceptions of writing. Unpublished Thesis for Master of Arts in Applied Linguistics, University of Hong Kong. Retrieved from https://hub.hku.hk/bitstream/10722/51743/6/FullText.pdf

Lam, S., \& Law, Y. (2010). The roles of instructional practices and motivation in writing performance. The Journal of Experimental Education, 75(2), 145-164. https://doi.org/10.3200/JEXE.75.2.145-164

Longknife, A., \& Sullivan, K. (2012). Easy writing skills. New York: The McGraw-Hill Companies, Inc.

Miltiadou, M., \& Savenye, W. C. (2003). Applying Social Cognitive Constructs of Motivation to Enhance Student Success in Online Distance Education. Educational Technology Review, 11(1), 1-28. Retrieved from https://www.learntechlib.org/primary/p/17795

Moallem, M. (2003). An interactive online course: A collaborative design model. Educational Technology Research and Development, 51(4), 85-103. https://doi.org/10.1007/BF02504545

Mohammed, S. (2010). Using electronic portfolios to develop EFL student teachers' writing performance and reflective thinking and reduce their writing apprehension. Ph.D dissertation, Faculty of Education, Suez Canal University.

Mostafa, A. (2002). The effectiveness of a proposed interactive process model in the writing performance, self-efficacy, and apprehension of ESP. Journal of Faculty of Education Mansoura University, 49, 77-102.

Oldfather, P., \& Shanahan, C. (2007). A cross-case study of writing motivation as empowerment. In S. Hidi \& P. Boscolo (Eds.), Writing and motivation (pp. 257-280). Bingley, UK: Emerald Group Publishing Limited.

Oshima, A., \& Houge, A. (2007). Introduction to academic writing (3rd edition). White Plains, N Y: Pearson Education, Inc.

Pajares, F. (2003). Social Cognitive Theory. In J. R. Miller, R. M. L B. Schiamberg \& P. M. Anderson (Eds.), Human Ecology: An encyclopedia of children, families, communities, and environments (Vol. 22, pp. 650653). Santa Barbara, CA:ABC-Clio.

Payne, A. (2012). Development of the academic writing motivation questionnaire. Published MA Thesis, Athens, Georgia: The University of Georgia.

Prat-Sala, M., \& Redford, P. (2010). Writing essays: Does self-efficacy Matter? The relationship between self-efficacy in reading and in writing and undergraduate students' performance in essay writing. Educational Psychology, 32(1), 9-20. https://doi.org/10.1080/01443410.2011.621411

Rich, C., Schneider, M. C., \& D' Brot, J. (2013). Applications of automated essay evaluation in West Virginia. In M. D. Shermis \& Burstein (Eds.), Handbook of Automated Essay Evaluation: Current Applications and New Directions (pp. 99-124). New York: Taylor \& Francis.

Ryan, R., \& Deci, E. (2000). Intrinsic and extrinsic motivations: Classic definitions and new directions. Contemporary Educational Psychology, 25, 54-67. https://doi.org/10.1006/ceps.1999.1020

Scott, S. (2008). Writing skills revisited. New York: Strategic Book Publishing.

Seliem, S., \& Ahmed, A. (2009). Missing: Electronic feedback in Egyptian EFL essay writing classes. Paper Presented at CDELT Conference, 2009, Faculty of Education, Ain Shams University, Egypt. Retrieved from https://files.eric.ed.gov/fulltext/ED505841.pdf

So, L., \& Lee, C. (2013). A case study on the effects of an 12 writing instructional model for blended learning in higher education. Turkish Online Journal of Educational Technology - TOJET, 12(4), 1-10. https://doi.org/10.1142/9789814449656_0001

Soureshjani, K. H. (2013). Self-Regulation and motivation reconsideration through Persian EFL learners' writing achievement (11060301). Journal of Research (Humanities), XLIX, 55-80. Retrieved from http://pu.edu.pk/images/journal/english/PDF/Article\%202\%20Kamal\%20Heidari_XLIX\%20JANUARY\%2 02013.pdf 
Tobin, L. (2001). Process pedagogy. In G. Tate, A. Rupiper \& K. Schick (Eds.), A guide to composition pedagogies (pp. 1-18). New York Oxford: Oxford University Press.

Tompkins, G. (2010). Teaching writing: Balancing process and product $\left(5^{\text {th }}\right.$ ed.). New York: Pearson.

Troia, G. A., Harbaugh, A. G., Shankland, R. K., Wolbers, K. A., \& Lawrence, A. M. (2013). Relationships between writing motivation, writing activity, and writing performance: Effects of grade, sex, and ability. Reading and Writing, 26(1), 17-44. https://doi.org/10.1007/s11145-012-9379-2

Yang, Y. (2014). Preparing language teachers for blended teaching of summary writing. Computer Assisted Language Learning, 27(3), 185-206. https://doi.org/10.1080/09588221.2012.701633

Zhang, Y., \& Guo, H. (2013). A study of English writing and domain-specific motivation and self-efficacy of Chinese EFL learners. Journal of Pan-Pacific Association of Applied Linguistics, 16(2), 103-123. Retrieved from http://210.101.116.28/W_files/kiss10/8g900079_pv.pdf

\section{Appendix A}

\section{Writing Motivation Questionnaire (WMQ)}

Dear students,

This questionnaire consists of 36 items and aims at identifying your motivation towards writing. Please choose the most appropriate response in front of each item of the questionnaire. Remember there is no right or wrong answer. All your responses are for scientific research purposes only.

Thanks for your cooperation.

\begin{tabular}{|c|c|c|c|c|c|}
\hline Items & $\begin{array}{l}\text { Strongly } \\
\text { Disagree }\end{array}$ & Disagree & Uncertain & Agree & $\begin{array}{l}\text { Strongly } \\
\text { Agree }\end{array}$ \\
\hline
\end{tabular}

\footnotetext{
Intrinsic motivation

1. I enjoy writing essays in English

2. I like to write down my thoughts and ideas.

3. I like to participate in written online discussions.

4. I enjoy writing assignments using D2L tools.

5. I like classes that require a lot of writing.

6. I enjoy writing assignments that challenge me.

7. I like to write even if my writing will not be graded.

8. I would like to have more opportunities to write in classes.

9. I practice writing in order to improve my skills.

10. I would rather write an essay than answer multiple-choice questions.

11. I want others to recognize me as a good student in writing English essays.

12. I am motivated (encouraged) to write in my classes.

Extrinsic motivation

13. Being good in writing English will help me do well in other courses.

14. I like to get feedback from my instructor on my writing.

15. I like my writing to be graded.

16. I am more likely to succeed if I can write well.

17. I like others to read my writings.

18. Becoming a better student in my writing class is important to me.

19. It is important to me that I make an A on a writing assignment.

20. Being able to write accurately in English is important in getting a good job.

21. I want the highest grade in the class on a writing assignment.

Self-efficacy

22. I use correct grammar in my writing.

23. I complete a writing assignment even when it is difficult.

24. I write as well as other students.

25. I am able to clearly express my ideas in writing

26. I easily focus on what I am writing.

27. It is easy for me to write good persuasive essays.

28. I can write essays with my group using D2L forums.

29. Developing transitional sentences between paragraphs is easy for me.

30. Choosing the right word is easy for me.
} 


\section{Effort}

31. I write more than the minimum on writing assignments.

32. I put a lot of effort into my writing.

33. I plan how I am going to write something before I write it

34. I revise my writing before submitting an assignment

35. I proofread and edit my writing.

36. I write several drafts for my writings.

\section{Appendix B}

\section{Writing Performance Test (WPT)}

Instructions:

Please write a persuasive five-paragraph essay on one of the topics given below. You will have 45 minutes to complete the essay. If you need more space, please turn over to continue.

\section{Prompt/topics:}

1) Some students choose their major fields of study according to their personal interests, while others are more concerned about job-market needs.

Which point of view do you support? Use specific reasons and examples to support your answer.

2) Some people believe that using computers every day can have more negative than positive effects on their life, while others think the vice versa. Which opinion do you support? Use specific reasons and examples to support your answer.

3) Some people believe that using smart phones have changed their lives positively, while others are against that thought. Which thought do you support? Use specific reasons and examples to support your answer.

\section{Appendix C}

\section{Writing Rubric}

\begin{tabular}{|c|c|c|c|c|c|}
\hline & \multirow[t]{2}{*}{$\begin{array}{l}\text { Organization } \\
(5-0) \text { scores }\end{array}$} & \multirow[t]{2}{*}{$\begin{array}{l}\text { Development } \\
\text { (content/ideas/support } \\
\text { and elaboration) } \\
(5-0) \text { scores }\end{array}$} & \multicolumn{3}{|l|}{ Conventions (15 scores) } \\
\hline & & & $\begin{array}{l}\text { Sentence structure (5- } \\
0) \text { scores }\end{array}$ & $\begin{array}{l}\text { Word usage }(5-0) \\
\text { scores }\end{array}$ & Mechanics (5-0) scores \\
\hline 5 & $\begin{array}{l}\text { - } \quad \text { Effectively } \\
\text { placed topic sentence } \\
\text { - } \quad \text { Clear and logical } \\
\text { order } \\
\text { - } \quad \text { Introductory } \\
\text { paragraph, supporting } \\
\text { paragraphs and } \\
\text { concluding paragraph } \\
\text { Purposeful transition } \\
\text { within and between } \\
\text { sentences, ideas and } \\
\text { paragraphs }\end{array}$ & $\begin{array}{l}\text { - Appropriate } \\
\text { development of the topic } \\
\text { for persuasive writing } \\
\text { - Appropriate thesis } \\
\text { statement and } \\
\text { development of } \\
\text { persuasive writing } \\
\text { - Clear progression } \\
\text { of ideas } \\
\text { - Clear use of } \\
\text { examples, evidence or } \\
\text { relevant details }\end{array}$ & $\begin{array}{l}\text { - Complete and } \\
\text { correct sentences } \\
\text { - Sentence } \\
\text { variation (simple, } \\
\text { compound, complex, } \\
\text { compound-complex) } \\
\text { - Variation of } \\
\text { phrases and clauses } \\
\text { (gerund, participial, } \\
\text { infinitive; subordinate } \\
\text { clauses) }\end{array}$ & $\begin{array}{l}\text { • } \\
\text { precise/concise, clear } \\
\bullet \quad \text { Mostly consistent } \\
\text { grammar usage } \\
>\quad \text { Subject/verb } \\
\text { agreement } \\
>\quad \text { Singular/plural } \\
\text { nouns } \\
>\quad \text { Verb (tense and } \\
\text { usage) } \\
>\quad \text { Pronoun usage } \\
\text { Adjective/Adverb }\end{array}$ & 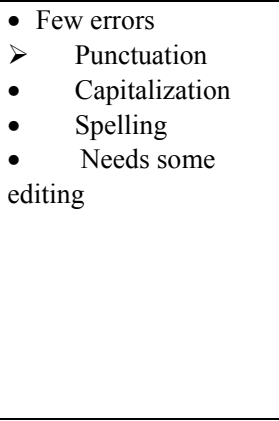 \\
\hline 4 & $\begin{array}{l}\text { - Clearly stated } \\
\text { topic sentence } \\
\text { - Evidence of a } \\
\text { logical order } \\
\text { - Introductory } \\
\text { paragraph, supporting } \\
\text { paragraphs and } \\
\text { concluding paragraph } \\
\text { Appropriate transition } \\
\text { within and between } \\
\text { sentences, ideas and } \\
\text { paragraphs }\end{array}$ & $\begin{array}{l}\text { - Sufficient } \\
\text { development of the topic } \\
\text { for persuasive writing } \\
\text { - } \quad \text { Sufficient thesis } \\
\text { statement and } \\
\text { development of } \\
\text { persuasive writing } \\
\text { - Progression of } \\
\text { ideas } \\
\text { - } \quad \text { Sufficient use of } \\
\text { examples, evidence } \\
\text { and/or relevant details }\end{array}$ & $\begin{array}{l}\text { - Complete and } \\
\text { correct sentences } \\
\text { - Sentence } \\
\text { variation (simple, } \\
\text { compound, complex, } \\
\text { compound-complex) } \\
\text { (errors in more } \\
\text { complex sentence } \\
\text { structure do not } \\
\text { detract) } \\
\text { - Variation of } \\
\text { phrases and clauses } \\
\text { (gerund, participial, } \\
\text { infinitive; subordinate } \\
\text { clauses) }\end{array}$ & $\begin{array}{l}\text { - Appropriate } \\
\text { specific } \\
\bullet \quad \text { Somewhat } \\
\text { consistent grammar } \\
\text { usage } \\
>\quad \text { Subject/verb } \\
\text { agreement } \\
>\quad \text { Singular/plural } \\
\text { nouns } \\
>\quad \text { Verb (tense and } \\
\text { usage) } \\
>\quad \text { Pronoun usage } \\
\text { Adjective/Adverb }\end{array}$ & 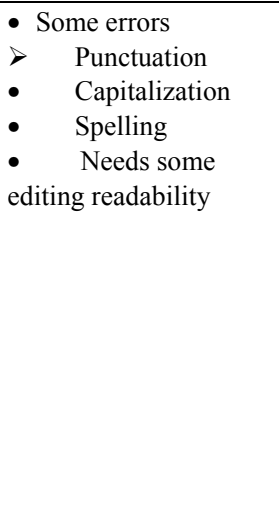 \\
\hline
\end{tabular}




\begin{tabular}{|c|c|c|c|c|c|}
\hline 3 & $\begin{array}{l}\text { - Poorly stated topic } \\
\text { sentence } \\
\text { - Some evidence } \\
\text { of organization } \\
\text { - Introductory } \\
\text { paragraph and } \\
\text { concluding paragraph } \\
\text { with limited supporting } \\
\text { paragraphs } \\
\text { Repetitive use of } \\
\text { transition }\end{array}$ & $\begin{array}{l}\text { - Limited } \\
\text { development of the topic } \\
\text { for persuasive writing } \\
\text { - Limited thesis } \\
\text { statement and } \\
\text { development of } \\
\text { persuasive writing } \\
\text { p Limited } \\
\text { progression of ideas } \\
\text { eximited use of } \\
\text { examples, evidence } \\
\text { and/or relevant details }\end{array}$ & $\begin{array}{l}\text { - Minor errors in } \\
\text { sentence structure } \\
\text { - Limited } \\
\text { sentence variation } \\
\text { (simple, compound, } \\
\text { complex, } \\
\text { compound-complex) } \\
\text { - (errors in more } \\
\text { complex sentence } \\
\text { structure begin to } \\
\text { detract) } \\
\text { p Limited use of } \\
\text { phrases and clauses } \\
\text { (gerund, participial, } \\
\text { infinitive; subordinate } \\
\text { clauses) }\end{array}$ & $\begin{array}{l}\text { - } \quad \text { Vague, redundant, } \\
\text { simplistic } \\
\text { - Several } \\
\text { inconsistencies in } \\
\text { grammar usage } \\
>\quad \text { Subject/verb } \\
\text { agreement } \\
>\quad \text { Singular/plural } \\
\text { nouns } \\
>\quad \text { Verb (tense and } \\
\text { usage) } \\
>\quad \text { Pronoun usage } \\
\text { Adjective/Adverb }\end{array}$ & $\begin{array}{l}\text { - } \text { Frequent errors } \\
\text { Punctuation } \\
\text { - } \quad \text { Capitalization } \\
\text { Begins to impede } \\
\text { readability }\end{array}$ \\
\hline 2 & $\begin{array}{l}\text { - Lack of acceptable } \\
\text { topic sentence } \\
\text { - Lacks clear } \\
\text { organizational pattern, } \\
\text { sequencing of ideas } \\
\text { and/or paragraphing } \\
\text { - May lack } \\
\text { introductory paragraph, } \\
\text { supporting paragraphs } \\
\text { and/or concluding } \\
\text { paragraph } \\
\text { Ineffective or overused } \\
\text { transition }\end{array}$ & $\begin{array}{l}\text { - Minimal } \\
\text { development of the topic } \\
\text { for persuasive writing } \\
\text { - Minimal thesis } \\
\text { statement and } \\
\text { development of } \\
\text { persuasive writing } \\
\text { p Lacks a logical } \\
\text { progression of ideas } \\
\text { - Minimal use of } \\
\text { examples, and/or } \\
\text { relevant details }\end{array}$ & $\begin{array}{l}-\quad \text { Contains } \\
\text { fragments and/or } \\
\text { run-ons } \\
\text { - Minimal } \\
\text { sentence variation } \\
\text { (simple, compound, } \\
\text { complex, } \\
\text { compound-complex) } \\
\text { (errors in sentence } \\
\text { structure detract) } \\
\text { Minimal use of } \\
\text { phrases and clauses } \\
\text { (gerund, participial, } \\
\text { infinitive; subordinate } \\
\text { clauses) }\end{array}$ & $\begin{array}{l}\text { - Inadequate, } \\
\text { imprecise, repetitive } \\
\text { - Frequent } \\
\text { inconsistencies in } \\
\text { grammar usage } \\
>\quad \text { Subject/verb } \\
\text { agreement } \\
>\quad \text { Singular/plural } \\
\text { nouns } \\
>\quad \text { Verb (tense and } \\
\text { usage) } \\
>\quad \text { Pronoun usage } \\
\text { Adjective/Adverb }\end{array}$ & $\begin{array}{ll}\text { - } & \text { Consistent errors } \\
> & \text { Punctuation } \\
> & \text { Capitalization } \\
\text { D } & \text { Spelling } \\
\text { - } & \text { Impedes readability }\end{array}$ \\
\hline 1 & $\begin{array}{l}\text { - Lacks stated } \\
\text { topic } \\
\text { - No logical } \\
\text { pattern; difficult to } \\
\text { follow } \\
\text { - Inadequate } \\
\text { paragraphing } \\
\text { Little or no transition }\end{array}$ & $\begin{array}{l}\text { - Little or no } \\
\text { development of the topic } \\
\text { for persuasive writing } \\
\text { - Unclear thesis } \\
\text { statement and } \\
\text { development of } \\
\text { persuasive writing } \\
\text { focus Unclear or no } \\
\text { examples, evidence } \\
\text { and/or relevant details }\end{array}$ & $\begin{array}{l}\quad \text { Contains } \\
\text { numerous fragments } \\
\text { and/or run-ons } \\
\text { - Little or no } \\
\text { sentence variation } \\
\text { (simple, compound, } \\
\text { complex, } \\
\text { compound-complex) } \\
\text { (errors in sentence } \\
\text { structure detract) } \\
\text { - Little or no use } \\
\text { of phrases and clauses } \\
\text { (gerund, participial, } \\
\text { infinitive; subordinate } \\
\text { clauses) }\end{array}$ & $\begin{array}{l}\text { • Rambling, } \\
\text { inappropriate, incorrect, } \\
\text { unclear } \\
\bullet \quad \text { Distracting } \\
\text { inconsistencies in } \\
\text { grammar usage } \\
>\quad \text { Subject/verb } \\
\text { agreement } \\
>\quad \text { Singular/plural } \\
\text { nouns } \\
>\quad \text { Verb (tense and } \\
\text { usage) } \\
>\quad \text { Pronoun usage } \\
\text { Adjective/Adverb }\end{array}$ & $\begin{array}{l}\text { - Serious and } \\
\text { consistent errors } \\
\text { Punctuation } \\
\text { Capitalization } \\
\text { - Impedes } \\
\text { understanding/communi } \\
\text { cation }\end{array}$ \\
\hline
\end{tabular}

- $\quad$ Rubric adapted from Rich, Schneider, D’ Brot (2013, pp. 108-109), with some modifications on the items.

- $\quad$ Rich, C., Schneider, M. C., D’ Brot, J. (2013). Applications of automated essay evaluation in West Virginia. (2013). In M.D Shermis \& Burstein (eds.), Handbook of Automated Essay Evaluation: Current Applications and New Directions (pp. 99-124). New York: Taylor \& Francis.

\section{Copyrights}

Copyright for this article is retained by the author, with first publication rights granted to the journal.

This is an open-access article distributed under the terms and conditions of the Creative Commons Attribution license (http://creativecommons.org/licenses/by/4.0/). 